Jurnal Magister Hukum Ekonomi Syariah

Vol 5, No 1 tahun 2021 hal 129-141

EISSN: 2614-865X PISSN: 2598-5043

Website: http://journal.um-surabaya.ac.id/index.php/JE/index

\title{
PEMANFAATAN TANAH NON-SERTIFIKASI MENURUT HUKUM PERJANJIAN BARAT \& ISLAM \\ (Studi Kasus Rencana Pemanfaatan Tanah oleh PT. Solusi Bangun Indonesia dengan Pemerintah Desa Sawir, Kecamatan Tambakboyo, Kabupaten Tuban)
}

\author{
Ario Patra Nugraha ${ }^{1}$ \\ Chamim Tohari \\ ${ }^{1}$ Universitas Brawijaya Malang \\ e-mail : ariopatranugroho@gmail.com \\ ${ }^{2}$ Universitas Muhammadiyah Surabaya \\ e-mail : chamimtoha@yahoo.com
}

\begin{abstract}
This research discusses about the status of land rights whose ownership has been not clear yet, which is the object of cooperation in utilization between the Sawir Village Government and PT Solusi Bangun Indonesia Tbk, according to the laws and principles in force in Indonesia. The problems that will be answered in this study include: (1) What is the status of land rights that are used as objects of utilization between the Sawir Village Government and PT Solusi Bangun Indonesia Tbk? (2) How is the land use cooperation between Sawir Village Government and PT Solusi Bangun Indonesia Tbk according to Western and Islamic Covenant Law? This type of research is a qualitative research, while the approach used is an empirical juridical approach, namely legal research that functions to see the laws that apply in the community. The results of this research are: (1) According to the Sawir Village Government, the land belongs to the Village Government as evidenced by the existence of a field map in the village $\mathrm{C}$ book. Meanwhile, according to the Tuban Regency Government, the Tuban Regency National Land Agency, and PT Solusi Bangun Indonesia Tbk, the land ownership is not registered and cannot be claimed as an asset of Sawir Village. According to Law Number 5 of 1960 concerning Basic Regulations on Agrarian Principles article 19 paragraph 1, the land cannot be referred to as land belonging to Sawir Village until the certification is completed on behalf of the village. And to get the ownership certificate, the Sawir Village Government must register or submit an application for ownership of the land to the National Land Agency of Tuban Regency. (2) According to the Islamic Covenant Law, the status of the land does not meet the requirements as an object of the agreement. This is because the land has not been legally proven to be owned by the Sawir Village Government. Whereas one of the main requirements for the validity of an agreement is that the object of the agreement must be legally owned by one of the parties who entered into the agreement.
\end{abstract}

Keywords: Utilization, Non-Certified Land, Covenant Law, Customary Rights.

\section{A. PENDAHULUAN}

Awal mula dari rencana Pemanfaatan Tanah ini adalah dengan adanya kejadian yaitu sebidang Tanah yang berada dalam wilayah Desa Sawir- Kecamatan Tambakboyo yang berbentuk memanjang yang di atasnya 
terdapat saluran air. Menurut catatan di Buku C milik Desa, Tanah tersebut ini tidak tercatat sebagai saluran air melainkan bidang tanah, secara kondisi di lapangan di atas tanah ini dibangun saluran air yang memanjang sejauh kurang lebih 2 (dua) km. ${ }^{1}$ Ternyata sebagian dari saluran air ini yaitu sekitar 10 (sepuluh) meter di atasnya harus dilewati oleh jalan akses tambang dari PT. Solusi Bangun Indonesia Tbk. karena hal inilah Pihak desa mengklaim bahwa tanah tersebut merupakan asset desa untuk dimanfaatkan menjadi peluang salah satu sumber Pendapatan Asli Desa.

Desa berdasarkan pasal 1 angka 1 Undang-Undang nomor 6 tahun 2014 tentang desa adalah kesatuan masyarakat hukum yang memiliki batas wilayah yang berwenang untuk mengatur dan mengurus urusan pemerintahan, kepentingan masyarakat, hak asal usul, dan/atau hak tradisional yang diakui dan dihormati dalam sistem Pemerintahan Negara Kesatuan Republik Indonesia.

Dalam kaitannya dengan tanah yang akan dijadikan objek pemanfaatan oleh desa maka tanah tersebut haruslah merupakan salah satu aset desa yang diakui dan dikelola secara legal formal. Sebagai pedoman pelaksanaan pengelolaan aset desa Pemerintah menerbitkan Peraturan Menteri dalam Negeri nomor 1 tahun 2016 tentang Pengelolaan Aset desa. Bentuk Pemanfaatan salah satu aset desa sebagiman diatur dalam pasal 11 Peraturan Menteri dalam Negeri ini meliputi, (1) Sewa ,(2) Pinjam pakai, (3) kerja sama pemanfaatan, (4) Bangun guna serah atau bangun serah guna. Pihak desa yang mengklaim sebagai salah satu asset desa tentunya perlu memahami pedoman pelaksanaanya.

Berdasarkan yang telah diuraikan oleh penulis, sebelum menentukan bentuk pemanfaatan perlunya memastikan status penguasaan tanah tersebut sebagai objek

\footnotetext{
${ }^{1}$ Wawancara dengan Imam Syafi'i, Kepala Desa Sawir, Tanggal 18 Februari 2020.
}

pemanfaatan yang dijadikan sebagai salah satu sumber Pendapatan Asli Desa dengan melakukan perjanjian yang akan disepakati nantinya. Namun demikian, semua hal di atas masih sebatas akan dan rencana, karena dalam pelaksanaan nantinya kedua belah pihak akan sangat berhati-hati dalam kaitannya dengan hukum sehingga jika tidak ada kepastian hukum terkait status tanah tersebut maka akan dicari solusi yang lain.

Walaupun Tanah ini sejatinya masuk dalam Izin Lokasi dari PT. Solusi Bangun Indonesia Tbk namun tanah ini tidak termasuk dalam perolehan Hak Atas Tanah yang telah dilakukan oleh PT. Solusi Bangun Indonesia Tbk. ${ }^{8}$ Menurut penelitian pendahuluan yang telah penulis lakukan, berdasarkan analisis awal kenapa tanah ini tidak dapat ditetapkan sebagai Hak atas tanah oleh PT Solusi Bangun Indonesia Tbk adalah sebagai berikut:

1. Di atas tanah tersebut terdapat saluran air yang bermuara pada sebuah bendungan. Karena dianggap saluran air tersebut merupakan sebuah fasilitas umum untuk warga maka tanah tersebut tidak dipindahtangankan.

2. Tanah yang belum jelas kepemilikannya atau penguasaanya, dalam buku $\mathrm{C}$ milik desa Sawir. Ditunjukkan dengan sebuah bidang tanah yang tercatat namun bukan sebuah saluran air dan tidak tercatat nama kepemilikan tanah tersebut

3. Pada kasus rencana pemanfaatan tanah oleh PT. Solusi Bangun Indonesia dengan Pemerintah Desa Sawir, Kecamatan Tambakboyo, Kabupaten Tuban, objek dari rencana pemanfaatan ini berupa Tanah yang di atasnya dibangun saluran air.

Namun sebelum melaksanakan kerja sama, pihak PT. Solusi Bangun Indonesia mensyaratkan agar tanah yang akan dijadikan objek pemanfaatan ini harus memiliki kepastian hukum yang tepat agar tidak terjadi penyimpangan di kemudian hari. Kepastian hukum yang tepat ini menuntut bahwa 
Pemerintah Desa Sawir harus dapat memberikan bukti pemilikan atau penguasaan hak atas Tanah tersebut. Menilik dari seluruh latar belakang di atas, isu hukum yang hendak penulis angkat dalam penelitian ini adalah terkait status tanah yang belum jelas kepemilikannya yang menjadi objek akad atau perjanjian Kerjasama, apakah sah menurut hukum atau sebaliknya, batal demi hukum.

Berdasarkan latar belakang tersebut maka rumusan masalah yang akan dibahas dalam penelitian ini adalah : Bagaimanakah status hak atas tanah yang akan dijadikan sebagai objek pemanfaatan antara Pemerintah Desa Sawir dengan PT Solusi Bangun Indonesia Tbk? (2) Landasan hukum apa yang dapat digunakan agar kerjasama pemanfaatan tanah antara Pemerintah Desa Sawir dengan PT Solusi Bangun Indonesia Tbk dapat dibenarkan secara hukum?

\section{B. METODE PENELITIAN}

Jenis penelitian ini adalah penelitian kualitatif, sedangkan pendekatan yang digunakan adalah pendekatan yuridis empiris, yaitu penelitian hukum yang berfungsi melihat hukum yang berlaku di lingkungan masyarakat. Dalam penelitian ini bahan hukum primer diambil dari data perbuatan hukum yang diperoleh langsung dari sumber pertama, yakni pihak-pihak yang terkait dengan pelaksanaan kerjasama pemanfaatan tanah yaitu (1) Kepala Desa Sawir, (2) Superitendent General Affair and Land Permiting PT Solusi Bangun Indonesia Tbk. Informan lebih lanjut ditentukan oleh informan awal, berdasarakan prinsip snow bolling. Agar mendapatkan data yang akurat dalam penelitian, maka dilakukan dengan tiga cara, yaitu: melalui wawancara, observasi dan studi kepustakaan. Model analisis kualitatif ang digunakan adalah model analisi data yang dilaksanakan dengan menggunakan tiga tahapan komponen yaitu reduksi data, sajian data, serta penarikan kesimpulan. verifikasi dalam tahapan tersebut dilakukan untuk agar data terkumpul dan saling berhubungan satu dengan yang lainnya.

\section{HASIL DAN PEMBAHASAN Status Hak Atas Tanah}

Status hak atas tanah yang akan dijadikan sebagai objek pemanfaatan antara Pemerintah Desa Sawir Dengan PT Solusi Bangun Indonesia Tbk dapat dijelaskan sebagai berikut: (1) Status hak atas tanah menurut para pihak. tanah tersebut adalah milik Pemerintah Desa yang dibuktikan dengan adanya peta bidang di buku $\mathrm{C}$ desa. Dengan demikian menurutnya pihak desa berhak menuntut hak mereka apabila terjadi pelanggaran aktivitas yang di timbulkan oleh PT Solusi Bangun Indonesia, misalnya dengan model pemanfaatan sewa, sehingga dengan cara tersebut warga desa Sawir dapat memperoleh keuntungan atau manfaat dari tanah tersebut. Sedangkan status hak atas tanah menurut Pemerintah Kabupaten Tuban, Badan Pertanahan Nasional Kabupaten Tuban, dan PT Solusi Bangun Indonesia Tbk, bahwa tanah tersebut tidak terdaftar kepemilikannya dan tidak dapat dilkaim sebagai aset Desa Sawir. (2) Status hak atas tanah menurut UUPA. Menurut UUPA, status hak atas tanah yang menjadi objek kerjasama pemanfaatan antara pemerintah Desa Sawir dengan PT Solusi Bangun Indonesia Tbk tersebut tidak dapat disebut sebagai tanah milik Desa Sawir sebelum diselesaikan sertifikasinya atas nama desa tersebut. Dan untuk mendapatkan sertifikat kepemilikan tersebut maka Pemerintah Desa Sawir harus mendaftarkan atau pengajukan permohonan kepemilikan atas tanah tersebut ke Badan Pertanahan Nasional Kabupaten Tuban. Hanya dengan pengakuan bahwa tanah tersebut telah diduduki turun temurun oleh warga Desa Sawir saja tidak dapat dijadikan sebagai argumentasi kepemilikan tanah, karena pandangan tersebut bersumber dari KUH 
Perdata dimana KUH Perdata itu sendiri telah dinyatakan tidak berlaku karena berkaitan dengan masalah pengaturan tanah, dan sudah diganti dengan peraturan-peraturan yang tercantum dalam UUPA sebagaimana dijelaskan sebelumnya.

\section{Status Hak Atas Tanah Objek Kerjasama Menurut Hukum Perjanjian}

Seperti yang telah dijelaskan pada bab sebelumnya bahwa perjanjian didefinisikan sebagai "suatu perbuatan hukum dimana seorang atau lebih mengikatkan dirinya terhadap seorang atau lebih." Dengan kata lain, perjanjian adalah suatu peristiwa dimana seorang berjanji kepada orang lain, atau dimana dua orang saling berjanji untuk melaksanakan sesuai. Burgelijk Wetbook (BW) dalam pasal 1313 BW menyatakan "Perjanjian adalah suatu perbuatan dengan mana satu orang atau lebih mengikatkan dirinya terhadap satu orang atau lebih". Menurut Subekti perjanjian adalah suatu peristiwa dimana seseorang berjanji kepada seorang lain atau dimana dua orang itu saling berjanji untuk melaksanakan sesuatu hal. Definisi lainnya menyebutkan bahwa perjanjian adalah "Suatu persetujuan baik tertulis maupun secara lisan yang dibuat oleh dua pihak atau lebih dimana kedua belah pihak mengatakan akan mentaati apa yang tersebut dalam isi persetujuan tersebut."

Istilah lainnya dari perjanjian adalah "Suatu perbuatan kesepakatan antara seseorang atau beberapa orang dengan seseorang atau beberapa orang lainnya untuk melakukan sesuatu perbuatan tertentu. Di dalam hukum jika perbuatan itu mempunyai akibat hukum maka prbuatan tersebut diistilahkan dengan perbuatan hukum. Adapun yang dimaksud dengan perbuatan hukum adalah segala perbuatan yang dilakukan oleh manusia secara sengaja untuk menimbulkan hak dan kewajiban. Dalam hal perbuatan hukum ini dapat diklasifikasikan menjadi dua, yaitu perbuatan hukum sepihak (yaitu perbuatan hukum yang dilakukan oleh satu pihak saja dan menimbulkan hak dan kewajiban pada satu pihak pula. Misalnya pembuatan surat wasiat), dan perbuatan hukum dua pihak (yaitu perbuatan hukum yang dilakukan oleh dua pihak dan menimbulkan hak-hak dan kewajibankewajiban bagi pihak lain. Misalnya persetujuan sewa-meyewa atau jual beli). Dari penjelasan tersebut dapat dipahami bahwa perbuatan hukum juga meliputi perjanjianperjanjian yang diadakan oleh para pihak.

Dalam hukum Islam, perjanjian disebut akad, yang mana di antara definisinya adalah "Pertalian antara ijab dan qabul menurut ketentuan syara' yang dapat menimbulkan akibat hukum pada objek atau dengan redaksi yang laian. Keterkaitan antara pembicaraan salah seorang yang melakukan aqad dengan yang lainnya menurut syara' pada segi yang tampak pengaruhnya pada objek." 2 Sedangkan ulama Syafi'iyah, Malikiyah dan Hanabilah mendefinisikan aqad sebagai "Segala sesuatu yang diniatkan oleh seseorang untuk dikerjakan, baik timbul karena satu kehendak seperti waqaf, pembebasan, talak dan sumpah, maupun yang memerlukan kepada dua kehendak di dalam menimbulkannya seperti jual beli, sewamenyewa, pemberian kuasa dan gadai."3

Menurut Mustafa Ahmad Zarqa', suatu akad merupakan ikatan secara hukum yang dilakukan oleh dua atau beberapa pihak yang sama-sama berkeinginan untuk mengikatkan diri. Kehendak atau keinginan pihak-pihak yang mengikatkan diri tersebut sifatnya tersembunyi dalam hati. Karena itu untuk menampakkan kehendak masing-masih maka harus diungkapkan dalam suatu pernyataan. Pernyataan pihak-pihak yang mengikatkan diri tersebut disebut dengan ijab dan qabul. Ijab adalah pernyataan pertama yang diungkapkan oleh salah satu pihak yang mengandung keinginan secara pasti untuk

\footnotetext{
2 Ahmad Wardi Muslih, Fiqh Muamalah, hlm. 111.

${ }^{3}$ Ibid, hlm. 112.
} 
mengikatkan diri. Sedangkan qabul adalah pernyataan pihak lain setelah ijab yang menunjukkan persetujuannya untuk mengikatkan diri. Jadi, perikatan dalam konteks fiqh lazim disebut sebagai akad. ${ }^{4}$

Terkait dengan apa yang telah diperjanjikan, maka masing-masing pihak haruslah saling menghormati terhadap apa yang telah mereka perjanjikan, sebab kewajiban tersebut disebutkan di dalam alQur'an di antaranya di dalam surat al-Maidah ayat 1 yang artinya, "Wahai orang-orang yang beriman, penuhilah akad-akad itu." Adapun yang dimaksud dengan akad dalam surat tersebut meliputi janji setia kepada Allah dan juga perjanjian yang dibuat oleh manusia dengan sesama manusia dalam pergaulan hidupnya sehari-hari.

Dari uraian tersebut maka dapat disimpulkan bahwa perjanjian merupakan suatu perbuatan hukum dimana pihak yang satu mengikatkan diri kepada pihak lainnya dimana dengan pengikatan tersebut memberikan pengaruh atau akibat hukum yang berupa timbulnya hak-hak dan kewajiban bagi pihak-pihak yang melakukan akad tersebut. Dari ketentuan hukum di atas, maka apapun alasannya, melanggar perjanjian termasuk perbuatan melanggar hukum, dan apabila seseorang telah melakukan suatu perbuatan melanggar hukum, maka pelakunya dapat dijatuhi hukuman yang mana dalam istilah Hukum Perdata disebut dengan "wanprestasi".

\section{Status Hak Atas Tanah Objek Kerjasama Menurut Hukum Perjanjian Barat}

Dalam hukum perjanjian Barat, suatu perjanjian harus memenuhi setidaknya tiga macam unsur, antara lain:

(1) Essentialia, yaitu unsur yang sangat penting/esensial dalam suatu perjanjian yang mana unsur tersebut harus ada. Misalnya dalam suatu perjanjian harus ada kata sepakat antara pihak-pihak yang mengadakan

\footnotetext{
${ }^{4}$ Nasrun Harun, Ensiklopedi Hukum Islam, hlm. 63.
}

perjanjian. Atau, di dalam perjanjian harus ada objek atau barang yang ditransaksikan.

(2) Naturalia, yaitu unsur perjanjian yang sewajarnya ada dan tidak boleh diabaikan oleh para pihak yang mengadakan suatu perjanjian. Misalnya, dalam pasal 1474 KUH Perdata disebutkan bahwa dalam perjanjian jual beli barang, penjual wajib menjamin cacat yang tersembunyi pada barang yang diperjualbelikan.

(3) Accidentalia, yaitu unsur perjanjian yang ad ajika dikehendaki oleh para pihak yang mengadakan perjanjian. Misalnya suatu perjanjian boleh dilakukan dalam bentuk sesuai yang dikehendaki oleh para pihak yang mengadakan perjanjian, baik dengan akte notaris maupun secara lisan.

Ketiga unsur perjanjian tersebut, terutama unsur essentialia, apabila dikaitkan dengan masalah status hak atas tanah yang menjadi objek kerjasama pemanfaatan antara pemerintah Desa Sawir dengan PT Solusi Bangun Indonesia Tbk, maka sebenarnya status tanah tersebut tidak memenuhi syarat sebagai objek perjanjian kerjasama pemanfaatan, karena belum menjadi milik/aset desa secara sah menurut hukum.

Untuk lebih jelasnya, keabsahan suatu perjanjian dalam hukum perjanjian Barat menurut pasal $1320 \mathrm{KUH}$ Perdata diharuskan memenuhi beberapa syarat berikut ini:

(1) Adanya kesepakatan antara pihak yang mengadakan perjanjian.

Yang dimaksud dengan sepakat mengikatkan diri adalah bahwa para pihak yang mengadakan perjanjian haruslah bersepakat atau menyetujui perkara-perkara yang pokok dari perjanjian yang diadakan tersebut. Artinya, apa yang dikehendaki oleh pihak yang satu juga dikehendaki oleh pihak lainnya. Adapun bentuk kesepakatan tersebut harus diberikan secara bebas, intinya menunjukkan bahwa semua pihak yang terlibat dalam perjanjian memiliki kesepakatan yang sama untuk melakukan sesuatu yang menjadi tujuan perjanjian 
tersebut. Kata sepakat haruslah didasarkan atas kemauan bebas, dan perjanjian baru dianggap sebagai perjanjian yang sah apabila didasarkan atas kesepakatan yang murni dan sempurna. Menurut pasal 1321 KUH Perdata, kata sepakat tidak didasarkan atas kemauan bebas atau tidak sempurna apabila didasarkan pada: a. Kekhilafan, yaitu keadaan dimana seseorang mempunyai pandangan yang sama terhadap orang atau barang. Menurut pasal 1322 KUH Perdata, kekhilafan tidak mengakibatkan batalnya suatu perjanjian selainnya apabila kelhilafan tersebut terjadi mengenai hakekat barang yang menjadi pokok perjanjian. b. Paksaan, yaitu suatu perbuatan yang dapat mengakibatkan timbulnya rasa takut bagi orang yang berakal sehat, dan perbuatan tersebut dapat menyebabkan terancamnya harta benda orang yang dipaksa. c. Penipuan, yaitu perbuatan seseorang yang dengan sengaja merugikan orang lain dengan cara menimbulkan kekhilafan pada diri orang lain. Menurut hukum perjanjian Barat, suatu perjanjian yang didasarkan pada kata sepakat yang tidak sempurna (karena terdapat unsur khilaf, paksaan, dan penipuan) tidak dengan sendirinya batal. Hal ini berbeda dengan hukum perjanjian dalam Islam dimana unsurunsur tersebut dianggap dapat membatalkan perjanjian.

(2) Kecakapan untuk membuat suatu perikatan

Orang yang terlibat dalam pembuatan perjanjian haruslah orang yang memiliki kecakapan secara hukum. Dalam pasal 1330 KUH Perdata disebutkan bahwa orang-orang yang tidak cakap untuk membuat suatu perjanjian antara lain: (a) orang yang belum dewasa, (b) mereka yang ditaruh dibawah pengampuan, (c) orang yang belum dewasa.

(3) Suatu hak tertentu

Maksudnya, barang yang menjadi objek perjanjian paling sedikit harus barang yang dikuasai, dimiliki atau menjadi hak salah satu pihak yang mengadakan perjanjian, barang yang dapat ditentukan jenisnya, berwujud, dan dalam jangkauan salah satu pihak yang bertransaksi dalam perjanjian tersebut.

(4) Suatu sebab yang diperbolehkan

Yang dimaksud dengan suatu sebab dalam hal ini adalah isi perjanjian itu sendiri. Jadi bukan sesuatu dibalik terjadinya perjanjian, atau apa yang menyebabkan suatu perjanjian tersebut diadakan. Suatu perjanjian dianggap tidak memenuhi persyaratan ketika isi perjanjian menyelisihi undang-undang atau nilai moralitas yang dipegang teguh masyarakat. Misalnya perjanjian jual beli barang-barang terlarang yang tidak diperbolehkan oleh undang-undang yang berlaku.

Syarat nomor 1 dan 2 disebut sebagai syarat subyektif, karena syarat tersebut merupakan syarat yang harus dipenuhi oleh subyek hukum dalam perjanjian. Adapun syarat nomor 3 dan 4 disebut sebagai syarat objektif karena syarat tersebut merupakan syarat yang harus dipenuhi oleh objek perjanjian. Apabila suatu perjanjian tidak memenuhi syarat obyektif maka akibat hukumnya adalah perjanjian tersebut batal demi hukum. Artinya, perjanjian tersebut dianggap tidak pernah terjadi. Tujuan para pihak yang mengadakan perjanjian tersebut untuk melahirkan suatu perikatan hukum menjadi gagal, dan tidak ada dasar untuk saling menuntut di muka hakim.

Status hak atas tanah yang menjadi objek kerjasama pemanfaatan antara pemerintah Desa Sawir dengan PT Solusi Bangun Indonesia Tbk, apabila dilihat dari syarat-syarat sahnya perjanjian di atas, maka dapat dikatakan bahwa seandainya perjanjian pemanfaatan tanah tersebut dilakukan, maka tidak memenuhi syarat objektif poin ke-3, karena obyek perjanjian harus terukur, menjadi milik atau dikuasai salah satu pihak yang mengadakan perjanjian, terukur dan dalam jangkauan. Sehingga status tanah yang belum menjadi milik desa tersebut apabila 
dijadikan objek perjanjian maka dengan sendirinya batal demi hukum.

\section{Status Hak Atas Tanah Objek Kerjasama Menurut Hukum Perjanjian Islam}

Dalam Hukum Perjanjian Islam, perjanjian sering disebut dengan istilah akad. Suatu akad dianggap sah apabila memenuhi rukun-rukun dan syarat-syaratnya.

$$
\text { Menurut ulama Hanafiyah }
$$

hakekatmya rukun akad itu hanya dua macam, yakni ijab dan qabul saja. Sedangkan unsurunsur lainnya yang menjadi penopang terjadinya akad seperti objek akad (mauqud 'alaih) dan pelaku akad ('aqidain) adalah unsur yang secara otomatis harus ada dalam pembentukan akad, hanya saja tidak menjadi bagian dari rukun akad. Berbeda denga para ulama Hanafiyah, jumhur ulama fiqh menepatkan bahwa rukun akad tidak hanya ijab dan qabul saja, melainkan termasuk unsurr-unsur yang dapat mendukung terwujudnya suatuu akad yang sempurna. Di antara rukun-rukun akad yang disepakati oleh para fuqaha di luar mazhab Hanafiyah adalah:

akad).

(1) 'Aqid (Orang yang melakukan

'Aqid adalah orang yang berakad (subjek akad). Bisa jadi masing-masing pihak yang terlibat dalam suatu akad terdiri dari salah satu orang, terkadang terdiri dari beberapa orang. Dalam kaitannya dengan 'aqid, setidaknya ada dua hal yang perlu diperhatikan, yakni tentang kecakapan $\left(\right.$ ahliyah) ${ }^{5}$ dan kekuasaan (wilayah) ${ }^{6}$ dari orang yang berakad.

(2) Ma'qud 'alaih (Objek akad).

5 Ahliyah dibagi menjadi dua, ahliyah al-wujub (kecakapan seseorang dalam menerima hak dan kewajiban) dan ahliyah al-ada' (kecakapan seseorang untuk melaksanakan hak dan kewajiban).

${ }^{6}$ Adapun pengertian wilayah adalah suatu kekuasaan yang diberikan oleh syara' yang emmungkinkan kepada pemiliknya untuk menimbulkan akad-akad dan tasarruf (tindakan hukum) dan melaksanakan akibatakibat hukum yang timbul dari akad tersebut.
Ma'qud 'alaih adalah objek akad atau benda-benda yang akan diakadkan, atau segala sesuatu yang dijadikan sasaran atau tujuan akad. Misalnya benda-benda yang dijual dalam akad jual beli, dalam akad hibah atau pemberian, gadai, dan utang.

(3) Maudhu' al-'aqid.

Maudhu' al-'aqid adalah tujuan atau maksud yang ingin dicapai ketika mengadakan akad. Berbeda akad maka berbedalah tujuan pokok akad. Dalam akad jual beli misalnya, tujuan pokoknya adalah memindahkan barang dari penjual kepada pembeli dengan cara memberi ganti.

(4) Shighat al-'aqid (Ijab dan Qabul).

Sighat al-'aqid adalah ijab qabul. Ijab adalah ungkapan yang pertama kali diucapkan oleh salah satu dari pihak yang melakukan akad. Menurut Wahbah Zuhaili, ijab adalah melakukan perbuatan khusus yang menunjukkan kerelaan yang timbul pertama dari pembicaraan salah seorang yang melakukan akad, atau yang menempati tempatnya, baik datangnya dari orang yang memberikan hak milik maupun dari orang yang menerima hak milik. ${ }^{7}$ Adapun qabul adalah pernyataan pihak kedua untuk menerimanya. Menurut Wahbah Zuhaili, qabul adalah penyataan yang disebutkan kedua kali dari ucapan salah seorang yang melakukan akad, yang menunjukkan kecocokan dan persetujuannya terhadap pernyataan yang disampaikan oleh orang yang pertama. ${ }^{8}$ Sedangkan menurut Muhammad Abu Zahrah, qabul adalah penyataan kedua yang timbul dari pelaku akad yang kedua. ${ }^{9}$

Adapun syarat-syarat dalam akad adalah sebagai berikut : (1) Kedua orang yang melakukan akad adalah orang yang cakap bertindak hukum. (2) Objek akad atau barang yang diakadkan dapat menerima hukumnya.

\footnotetext{
${ }^{7}$ Wahbah Zuhaili, Fiqh Islam wa Adillatuhu, hlm. 93.

8 Ibid.

9 Muhamamd Abu Zahrah, Al-Milkiyah wa Nazhariyah al-Aqh di al-Syari'ah al-Islamiyah, Dar al-Fikr, Beirut, 1976, hlm. 202.
} 
(3) Akad yang dilakukan bukan akad yang dilarang oleh syari'at Islam, seperti akad jual beli barang yang diharamkan. (5) Ijab dilakukan berjalan terus dan tidak terputus, atau tidak dicabut sebelum terjadi qabul.

Agar suatu akad yang dilakukan oleh pihak penjual dan pembeli sah secara hukum, maka harislah dipenuhi beberapa syarat-syarat yang berkaitan dengan hal-hal berikut:

(a) Berkaitan dengan subjeknya: (1) Kedua belah pihak yang melakukan perjanjian akadharuslah orang yang berakal sehat, karena itu bertransaksi dengan orang gila dan atau bodoh dapat mengakibatkan tidak sah akadyang dilakukan. (2) Akadharus dilakukan dengan kesadaran dan kehendaknya sendiri, tidak ada paksaan. (3) Kedua belah pihak yang melakukan transaksi harus sudah baligh usianya. Dan (4) Akadyang dilakukan tidak terhadap sesuatu yang mubadzir atau tidak ada manfaatnya.

(b) Berkaitan dengan Objeknya, maka yang dimaksud dengan objek akad di sini adalah benda yang menjadi sebab terjadinya perjanjian. Adapun benda tersebut haruslah memenuhi syarat-syarat sebagai berikut: (1) Bersih barangnya, artinya barang yang diperjualbelikan bukanlah benda yang dikualifikasikan sebagai benda najis atau diharamkan untuk dikonsumsi atau dipergunakan. (2) Dapat dimanfaatkan, artinya kemanfaatan barang tersebut sesuai dengan ketentuan hukum syariah Islam yang tidak bertentangan dengannya. (3) Milik orang yang melakukan akad, artinya orang yang melakukan perjanjian akadatas sesuatu barang adalah pemilik sah barang tersebut atau telah mendapatkan ijin dari pemiliknya yang sah. (4) Mampu menyerahkan, artinya pihak penjual (baik sebagai pemilik maupun sebagai kuasa) dapat menyerahkan barang yang dijadikan sebagai objek akadsesuai dengan bentuk dan jumlah yang diperjanjikan pada waktu penyerahan barang kepada pihak pembeli. (5) Barang dapat diketahui keadaannya, artinya apabila dalam suatu akad akadkeadaan barang dan jumlah harganya tidak diketahui, maka perjanjian akadhukumnya tidak sah. Sebab bisa jadi perjanjian tersebut mengandung unsur penipuan. Dan (6) Barang yang diakadkan ada ditangan penjual, artinya akad dilarang apabila dilakukan dalam keadaan barang yang diperjualbelikan belum ada di tangan penjual. Karena bisa jadi barang yang belum ditangan tersebut memiliki kerusakan yang tidak dapat diketahui oleh pembeli, atau tidak dapat diserahkan oleh penjualnya. ${ }^{10}$

Berkaitan dengan syarat sahnya obyek perjanjian dalam Islam, disitu jelas bahwa salah satunya adalah barang yang menjadi objek perjanjian merupakan barang yang dimiliki oleh pelaku akad atau perjanjian. Jika barang tersebut tidak berada dalam kekuasaan atau kepemilikan pihak yang berakad, maka perjanjian terkait barang tersebut batal dan tidak sah menurut hukum Islam.

Adapun yang hendak penulis tekankan pada bagian ini adalah bahwa baik menurut hukum positif maupun hukum Islam, suatu perjanjian hanya dapat sah secara hukum apabila objek perjanjian atau barang yang digunakan sebagai bahan perjanjian secara sah dimiliki oleh salah satu pihak yang melakukan perjanjian. Terkait dengan hal tersebut, maka status tanah yang menjadi objek perjanjian kerjasama pemanfaatan antara pemerintah Desa Sawir dengan PT Solusi Bangun Indonesia Tbk, semestinya tidak memenuhi syarat sebagai objek perjanjian. Hal itu karena tanah tersebut secara yuridis belum terbukti sebagai tanah milik Pemerintah Desa Sawir.

Sampai di sini yang dapat disimpulkan dari sus bab pembahasan ini adalah bahwa status hak atas tanah yang menjadi objek perjanjian kerjasama pemanfaatan antara Pemerintah Desa Sawir dengan PT Solusi Bangun Indonesia Tbk menurut pihak Pemerintah Desa Sawir adalah aset desa, sedangkan menurut pihak Pemerintah Daerah

\footnotetext{
${ }^{10}$ Ahmad Wardi Muslih, Fiqh Muamalah, hlm. 150.
} 
Kabupaten Tuban, menurut Badan Pertanahan Nasional (BPN) Tuban, serta menurut PT Solusi Bangun Indonesia Tbk adalah tanah yang belum dimiliki oleh Pemerintah Desa Sawir karena tidak adanya bukti yuridis yang bisa ditunjukkan (seperti sertipikat tanah). Selain itu, status hak atas tanah tersebut menurut UUPA dianggap belum secara sah menjadi milik desa karena belum didaftarkan hak kepemilikannya ke kantor BPN Tuban. Sedangkan menurut Hukum Perjanjian, baik Hukum Perjanjian Barat maupun Hukum Perjanjian Islam, status tanah yang menjadi objek perjanjian kerjasama pemanfaatan antara pemerintah Desa Sawir dengan PT Solusi Bangun Indonesia Tbk, tidak memenuhi syarat sebagai objek perjanjian. Hal itu karena tanah tersebut secara yuridis belum terbukti sebagai tanah milik Pemerintah Desa Sawir. Padahal salah satu syarat pokok sahnya suatu perjanjian adalah objek perjanjian harus telah sah secara hukum menjadi milik salah satu pihak yang mengadakan perjanjian tersebut.

\section{Landasan Hukum Pemanfaatan Tanah Berdasarkan Hak Ulayat}

Pada bagian sebelumnya telah dibahas bahwa status tanah yang menjadi objek perjanjian kerjasama pemanfaatan antara pemerintah Desa Sawir dengan PT Solusi Bangun Indonesia Tbk, tidak memenuhi syarat sebagai objek perjanjian. Hal itu karena tanah tersebut secara yuridis belum terbukti sebagai tanah milik Pemerintah Desa Sawir. Selanjutnya, langkah apa yang sekiranya dapat dibenarkan secara hukum agar kerjasama pemanfaatan tanah tersebut dapat terealisasi? Dalam penelitian ini penulis mengusulkan beberapa landasan yuridis yang dapat digunakan oleh Pemerintah Desa Sawir agar kerjasama pemanfaatan tanah tersebut dapat terealisasi dan diakui keabsahannya secara hukum.

Sebagaimana umumnya pemerintahan yang mempunyai pimpinan, masyarakat hukum juga dipimpin oleh seorang pimpinan yaitu ketua adat dan dibantu oleh para pembantunya. Masyarakat hukum mempunyai kedaulatan penuh (sovereign) atas wilayah kekuasaannya (tanah ulayat) dan melalui ketua adat juga mempunyai kewenangan (authority) penuh untuk mengatur dan menata hubungan-hubungan di antara sesama masyarakat serta hubungan antara warga dengan alam sekitarnya. Pengaturan dan penataan hubungan-hubungan tersebut bertujuan untuk mencari keseimbangan hubungan, sehingga tercipta ketentraman dan kedamaian dalam kehidupan masyarakat. Adapun kedaulatan dan kewenangan masyarakat hukum tersebut berdasarkan atas suatu hak yaitu hak ulayat yang dimiliki secara turun temurun oleh masyarakat hukum tersebut.

Meskipun di dalam Pasal 3 UUPA terdapat istilah "hak ulayat dan hak-hak yang serupa dengan itu", namun pada dasarnya keberadaan UUPA tidak secara terperinci mendefinisikan apa yang dimaksud dengan tanah umayat tersebut. Di antara para pakar hukum tidak ada yang kesamaan pendapat terkait definisi hak ulayat. Boedi Harsono misalnya, berpendapat bahwa hal ulayat merupakan serangkaian wewenang dan kewajiban suatu masyarakat hukum adat yang berhubungan dengan tanah yang terletak dalam lingkungan wilayahnya, yang merupakan pendukung utama kehidupan dan penghidupan masyarakat yang bersangkutan sepanjang masa. ${ }^{11}$

Sampai di sini dapat penulis katakan bahwa apabila menilik sejarah status hak milik tanah objek kerjasama pemanfaatan antara Pemerintah Desa Sawir dengan PT Solusi Bangun Indonesia Tbk di atas, meskipun tanah tersebut belum berstatus resmi sebagai aset desa, tetapi tanah tersebut dapat diklaim sebagai tanah ulayat karena selain lokasinya yang berada di wilayah Desa

${ }^{11}$ Boedi Harsono, Hukum Agraria Indonesia, Jambatan, Jakarta, 2003, hlm. 185. 
Sawir, juga tanah tersebut telah dimanfaatkan secara turun-temurun oleh warga desa tersebut. Sehingga dengan demikian tanah tersebut memiliki fungsi yang sama dengan tanah ulayat yang boleh diambil manfaatnya oleh warga yang dalam hal ini dikelola oleh Pemerintah Desa Sawir. Masyarakat Desa sawir, Kecamatan Tambakboyo, Kabupaten Tuban dalam hal ini direpresentasikan oleh Pemerintah Desa Sawir yang berperan sebagai subjek atau pemohon hak atas tanah sebagai suatu masyarakat hukum adat. Maka dalam hal ini berkah memperoleh 2 (dua) macam Hak Tanah, yaitu Hak Pakai atau Hak Pengelolaan.

Jauh sebelum masuknya bangsa penjajah ke nusantara, wilayah kepulauan Indonesia telah dihuni oleh berbagai bentuk persekutuan hukum (rechtsgemeenschap) yang mempunyai masyarakat yang teratur, mempunyai pemerintahan sendiri seperti kepala persekutuan hukum dan pembantupembantunya, serta mempunyai harta material maupun immaterial. Persekutuan hukum ini juga disebut dengan istilah "masyarakat hukum", yaitu sekelompok manusia yang teratur dan bersikap, mempunyai pemerintahan atau pimpinan serta mempunyai kekayaan sendiri baik berupa benda yang dapay dilihat mata (material) maupun benda yang tidak dapat dilihat mata (immaterial).

Sebagaimana umumnya pemerintahan yang mempunyai pimpinan, masyarakat hukum juga dipimpin oleh seorang pimpinan yaitu ketua adat dan dibantu oleh para pembantunya. Masyarakat hukum mempunyai kedaulatan penuh (sovereign) atas wilayah kekuasaannya (tanah ulayat) dan melalui ketua adat juga mempunyai kewenangan (authority) penuh untuk mengatur dan menata hubungan-hubungan di antara sesama masyarakat serta hubungan antara warga dengan alam sekitarnya. Pengaturan dan penataan hubungan-hubungan tersebut bertujuan untuk mencari keseimbangan hubungan, sehingga tercipta ketentraman dan kedamaian dalam kehidupan masyarakat. Adapun kedaulatan dan kewenangan masyarakat hukum tersebut berdasarkan atas suatu hak yaitu hak ulayat yang dimiliki secara turun temurun oleh masyarakat hukum tersebut.

Meskipun di dalam Pasal 3 UUPA terdapat istilah "hak ulayat dan hak-hak yang serupa dengan itu", namun pada dasarnya keberadaan UUPA tidak secara terperinci mendefinisikan apa yang dimaksud dengan tanah umayat tersebut. Di antara para pakar hukum tidak ada yang kesamaan pendapat terkait definisi hak ulayat. Boedi Harsono misalnya, berpendapat bahwa hal ulayat merupakan serangkaian wewenang dan kewajiban suatu masyarakat hukum adat yang berhubungan dengan tanah yang terletak dalam lingkungan wilayahnya, yang merupakan pendukung utama kehidupan dan penghidupan masyarakat yang bersangkutan sepanjang masa. ${ }^{12}$

Definisi lainnya dikemukakan oleh Imam Sudiyat yang mengatakan bahwa hak ulayat adalah hak purba, yaitu suatu hak yang dimiliki oleh suatu suku, sebuah serikat desadesa, atau biasanya dimiliki oleh sebuah desa saja untuk menguasai seluruh tanah dan seisinya dalam lingkungan wilayahnya. ${ }^{13}$

Ardiwilaga R Roestandi mendefinisikan hak ulayat sebagai suatu hak dari persekutuan hukum untuk menggunakan secara bebas tanah-tanah yang masih merupakan hutan belukar di dalam lingkungan wilayahnya guna kepentingan persekutuan hukum itu sendiri dan anggotaanggotanya atau guna kepentingan orangorang luaran (orang mendatang, orang asing) akan tetapi dengan ijinnya dan senantiasa dengan pembayaran pengakuan rekognisi, dalam pada itu persekutuan hukum itu tetap campur tangan, secara keras maupun tidak,

\footnotetext{
12 Boedi Harsono, Hukum Agraria Indonesia, Jambatan, Jakarta, 2003, hlm. 185.

13 Imam Sudiyat, Hukum Adat Sketsa Asas, Liberty, Yigyakarta, 1998, hlm. 2.
} 
juga atas tanah-tanah yang telah diusahakan orang yang terletak di dalam lingkungan wilayahnya.

Van Vollenhoven mengemukakan bahwa yang dimaksud dengan hak ulayat adalah beschikkingsrecht yang kemudian diterima oleh umum dan masih digunakan hingga sekarang. Hak ulayat menggambarkan hubungan antara masyarakat hukum adat dengan tanah yang dikuasainya tersebut. Terdapat dua hal yang menyebabkan sehingga tanah memiliki kedudukan yang sangat penting dalam hukum adat, yaitu: (1) Karena sifatnya, tanah merupakan satu-satunya benda kekayaan yang bersifat tetap dalam keadaannya sebagai benda yang nyata. (2) Karena faktanya, bahwa tanah merupakan tempat tinggal dan memberikan penghidupan bagi masyarakat hukum adat, tempat pemakaman leluhurnya, serta tempat tinggal roh leluhur masyarakat adat tersebut.

Pasal 1 Nomor 1 Peraturan Menteri Negara Agraria/Kepala Badan Pertanahan Nasional Nomor 5 Tahun 1999 Tentang Pedoman Penyelesaian Masalah Hak Ulayat Masyarakat Hukum Adat menyatakan bahwa hak ulayat dan yang serupa dengannya dari masyarakat hukum adat (untuk selanjutnya disebut hak ulayat) adalah suatu kewenangan yang menurut hukum adat dimiliki oleh masyarakat hukum adat tertentu atas wilayah tertentu yang merupakan lingkungan hidup para warganya untuk mengambil manfaat dari sumber daya alam, termasuk tanah, dalam wilayah tersebut, bagi kelangsungan hidup dan kehidupannya, yang timbul dari hubungan secara lahiriyah dan batiniyah secara turun temurun dan tidak terputus antara masyarakat hukum adat tersebut dengan wilayah yang bersangkutan.

Dari beberapa definisi tersebut maka dapat disimpulkan bahwa subjek hak ulayat adalah masyarakat hukum adat, sedangkan objek hak ulayat adalah seluruh tanah dan apa yang ada di dalamnya yang berada di wilayah kekuasaan masyarakat hukum adat. Selain tanah dan seisinya (kekayaan alam yang terkandung di dalam tanah ulayat), objek hak ulayat juga termasuk air (sungai, danau, dan laut di sekitar pantai), binatang liar yang hidup di hutan dan pohon-pohon yang ada di hutan yang belum dimiliki oleh perorangan.

Dalam hukum Islam, hak ulayat memiliki kemiripan dengan konsep ihraz, yaitu menguasai atau memiliki sesuatu properti yang belum ada pemiliknya, atau mengelola dan mengambil manfaatnya dengan cara memilikinya. Ihraz menjadi sah secara hukum apabila memenuhi dua syarat, yaitu (1) Properti tersebut belum bertuan atau belum ada pemiliknya, dan (2) Orang yang mengambil properti tersebut memiliki keinginan atau tujuan untuk menguasainya. Menurut para ulama dari kalangan mazhab Hanafi, kedua syarat tersebut harus terpenuhi untuk mendapatkan hak dengan jalan ihraz. Menurut mazhab ini, ihraz tidak disyaratkan bahwa subyek hukum harus memiliki kemampuan dan kecakapan yang sempurna untuk melakukan tindakan hukum, selama orang mampu mengelola properti - baik itu tanah, hutan, dan sebagainya - dengan baik, maka ia dianggap berhak memilikinya. ${ }^{14}$

Sampai di sini jelaslah bahwa hak ulayat adalah hak menguasai dan memanfaatkan suatu wilayah yang terdapat di sekitaran masyarakat hukum adat, yang mana wilayah tersebut telah lama ditempati dan pergunakan sebagai fasilitas hidup masyarakat hukum adat sejak lama. Karena itu hak ulayat memiliki kekuatan berlaku ke dalam dan ke luar seperti yang telah dijekaskan di atas.

\section{KESIMPULAN}

Status hak atas tanah yang akan dijadikan sebagai objek pemanfaatan antara Pemerintah Desa Sawir Dengan PT Solusi Bangun Indonesia Tbk adalah milik Pemerintah Desa yang dibuktikan dengan

\footnotetext{
${ }^{14}$ Chamim Tohari, Konsep Hak Dalam Pemikiran Fiqh Hanafiyah, Jurnal Ahkam Volume 6, Nomor 1, Juli 2018, hlm. 63.
} 
adanya peta bidang di buku $\mathrm{C}$ desa. Dengan demikian menurutnya pihak desa berhak menuntut hak mereka apabila terjadi pelanggaran aktivitas yang di timbulkan oleh PT Solusi Bangun Indonesia, misalnya dengan model pemanfaatan sewa, sehingga dengan cara tersebut warga desa Sawir dapat memperoleh keuntungan atau manfaat dari tanah tersebut. Sedangkan status hak atas tanah menurut Pemerintah Kabupaten Tuban, Badan Pertanahan Nasional Kabupaten Tuban, dan PT Solusi Bangun Indonesia Tbk, bahwa tanah tersebut tidak terdaftar kepemilikannya dan tidak dapat dilkaim sebagai aset Desa Sawir. Status hak atas tanah menurut UUPA. Menurut UUPA, status hak atas tanah yang menjadi objek kerjasama pemanfaatan tersebut tidak dapat disebut sebagai tanah milik Desa Sawir sebelum diselesaikan sertifikasinya atas nama desa tersebut. Status hak atas tanah menurut Hukum Perjanjian
Barat maupun Hukum Perjanjian Islam, status tanah tersebut tidak memenuhi syarat sebagai objek perjanjian. Hal itu karena tanah tersebut secara yuridis belum terbukti sebagai tanah milik Pemerintah Desa Sawir. Padahal salah satu syarat pokok sahnya suatu perjanjian adalah objek perjanjian harus telah sah secara hukum menjadi milik salah satu pihak yang mengadakan perjanjian tersebut. Ketika tanah tersebut tidak dapat dibuktikan kepemilikannya secara yuridis oleh pihak Pemerintah Desa Sawir, maka tidak berarti tanah tersebut tidak dapat dimanfaatkan. Kerjasama pemanfaatan atas tanah tersebut tetap dapat dilakukan dengan berdasarkan pada Hak ulayat, karena sudah diwariskan sejak dahulu secara turun temurun oleh warga desa Sawir sebelum diserahkan kepada Pemerintah Desa Sawir untuk dibangun di atasnya sebuah saluran irigasi guna mengairi area pertanian di desa tersebut.

\section{REFERENSI}

[1] Achmad, Ali, Menguak Tabir Hukum (suatu Kajian Filosofid dan Sosiologis), Toko Gunung Agung, Jakarta, 2002.

[2] 'Âshûr, Muhammad Thâhîr Ibn, Maqâshid al-Sharî’ah al-Islâmiyyah, Dar al-Fikr, Beirut, 1979.

[3] Firdaus, Emilda, Badan Permusyaaratan Desa dalam Tiga Periode Pemerintahan Indonesia, Jurnal, Ilmu Hukum, Vol. 2 No 2 Februari 2006.

[4] Harsono, Boedi, Hukum Agraria Indonesia, Universitas Trisakti, Jakarta, 2013.

[5] H. Muchsin dkk, Hukum Agraria Indonesia dalam perspektif Sejarah, Refika Aditama, Bandung, 2007.

[6] Harun, Nasrun, Ensiklopedi Hukum Islam, PT Ihktiar Baru Van Hoeve, Jakarta, 2003.

[7] J. Rawis, A Theory of Justice, Harvard Universit Press, Massachusetts, 2000.

[8] Kansil, Pengantar Ilmi Hukum dan Tata Hukum Indonesia, Balai Pustaka, Jakarta, 1989.

[9] Moleong, Lexy J., Metodologi Penelitian Kualitatif, Remaja Rosdakarya Offset, Bandung.

[10] Muslehuddin, Muhammad, Philosophy of Islamic Law and the Orientalist, Taj Company, New Delhi, 1986.

[11] Muslih, Ahmad Wardi, Fiqh Muamalah, Amzah, Jakarta, 2013.

[12] Oksafiama, Linda dkk, Pemanfaatan Aset Desa Dalam Upaya Meningkatkan Pendapatan Desa, Jurnal Suara Keadilan, Volume 18, No 2, 2017.

[13] Permadi, Iwan. Kedudukan Hukum Persewaan Tanah Negara, Jurnal ARENA HUKUM Volume 9, Nomor 2, Agustus 2016. 
[14] Pide, Suriyaman Mustari, Hukum Adat, Dahulu, Kini, dan Mendatang, Prenada, Jakarta, 2015.

[15] Ramli, Zein, Hak Pengelolaan Dalam Sistem UUPA, Rineka Cipta, Jakarta, 1995.

[16] Said, Sampara dkk, Pengantar Ilmu Hukum, Total Media, Yogyakarta, 2011.

[17] Salim, HS, Perkembangan Teori Dalam Ilmu Hukum, Rajawali Pers, Jakarta, 2010.

[18] Santoso, Hukum Agraria Kajian Komprehensif, Prenada Media, Jakarta, 2005

[19] Soekanto, Soerjono, dkk, Penelitian Hukum Normatif Suatu Tinjauan Singkat, Rajawali Pers, Jakarta, 1985.

[20] Subekti, Hukum Perjanian, Intermasa, Jakarta, 2005.

[21] Sutedi, Adrian, Sertifikat Hak Atas Tanah, Cet.3, Sinar Grafika, Jakarta, 2014.

[22] Tohari, Chamim, Konsep Hak Dalam Pemikiran Fiqh Hanafiyah, Jurnal Ahkam Volume 6, Nomor 1, Juli 2018.

[23] Zahrah, Muhamamd Abu, Al-Milkiyah wa Nazhariyah al-Aqh di al-Syari'ah al-Islamiyah, Dar al-Fikr, Beirut, 1976.

[24] Zuhaili, Wahbah, Fiqh al-Islam, Dar al-Ma'rifah, Damaskus, 1789 H.

[25] Tohari, Chamim, Konsep Hak Dalam Pemikiran Fiqh Hanafiyah, Jurnal Ahkam Volume 6, Nomor 1, Juli 2018. 